\title{
Streptococcal SspB Peptide Analog Inhibits Saliva-Promoted Adhesion and Biofilm Formation of Streptococcus mutans
}

\author{
Tatsuro Ito ${ }^{1,2 *}$, Takahiro Ichinosawa1, Nana Ikematsu-Ito ${ }^{1}$, Chihiro Watanabe ${ }^{1}$, \\ Takehiko Shimizu1,2 \\ ${ }^{1}$ Department of Pediatric Dentistry, Nihon University School of Dentistry at Matsudo, Chiba, Japan \\ ${ }^{2}$ Nihon University Research Institute of Oral Science, Chiba, Japan \\ Email: *ito.tatsuro@nihon-u.ac.jp
}

Received 6 February 2016; accepted 27 March 2016; published 30 March 2016

Copyright @ 2016 by authors and Scientific Research Publishing Inc.

This work is licensed under the Creative Commons Attribution International License (CC BY). http://creativecommons.org/licenses/by/4.0/

(c) () Open Access

\section{Abstract}

Background: Streptococcus gordonii, a pioneer colonizer of dental plaque biofilm, expresses surface protein adhesin SspB by which the bacteria bind to salivary agglutinin (gp340). SspB has extensive homology with PAc, a surface adhesin of Streptococcus mutans. Hence, SspB of $S$. gordonii competes with PAc of $S$. mutans for the same niche environment in the salivary pellicles. The aim of this study was to develop anti-adherence agents that enabled us to control cariogenic biofilms by using the streptococcal SspB peptide analog SspB (A4K-A11K). Methods: First, we performed ELISA to determine the $S$. mutans-saliva interaction and saliva-binding activities of SspB (A4KA11K). The inhibitory effects of SspB (A4K-A11K) were then evaluated by examining $S$. mutans adhesion to saliva-coated hydroxyapatite disks (s-HA). To determine peptide interference with biofilm formation, $S$. mutans biofilms were quantified by counting CFUs on MS agar plates and by measuring the absorbance at $492 \mathrm{~nm}$ of safranin-stained biofilms on s-HA. Results: Saliva, particularly salivary gp340 peptide, promoted adherence of $S$. mutans to polystyrene surfaces. SspB (A4K-A11K) significantly bound to saliva and inhibited the adhesion of $S$. mutans to s-HA without bactericidal activity. Furthermore, biofilms of $S$. mutans on s-HA were successfully reduced by pretreatment with SspB (A4K-A11K). Conclusion: SspB (A4K-A11K) peptide competitively blocked $S$. mutans adhesion to experimental pellicles through SspB-gp340 interaction, thereby inhibiting biofilm formation. These findings will contribute to the control cariogenic biofilms.

\section{Keywords}

SspB, Biofilm, Streptococcus mutans, Saliva, gp340

\footnotetext{
${ }^{*}$ Corresponding author.
}

How to cite this paper: Ito, T., Ichinosawa, T., Ikematsu-Ito, N., Watanabe, C. and Shimizu, T. (2016) Streptococcal SspB Peptide Analog Inhibits Saliva-Promoted Adhesion and Biofilm Formation of Streptococcus mutans. Open Journal of Stomatology, 6, 81-89. http://dx.doi.org/10.4236/ojst.2016.63010 


\section{Introduction}

Streptococcus mutans is the predominant etiological agent of human dental caries [1] [2]. Many reports have shown correlations between elevated numbers of this organism in dental plaque biofilms and the presence of caries (reviewed by [3]). The initial adhesion of $S$. mutans to salivary acquired enamel pellicles contributes to dental biofilm maturation [4]. S. mutans interacts with salivary proteins, such as innate immunity scavenger receptor glycoprotein-340 (gp340) [5], by means of the cell surface protein antigen PAc [6], variously designated as antigen AgI/II [7], B [8], P1 [9], and MSL-1 [10].

Streptococci compete for adhesion binding sites on the saliva-coated tooth surface [11]. Streptococcus gordonii, a pioneer colonizer of dental plaque biofilms, produces surface protein adhesin SspB by which the bacteria bind to enamel pellicles. SspB, which also interacts with salivary gp340, has extensive homology with PAc in $S$. mutans [10] [12]; hence, S. gordonii competes with $S$. mutans for the same niche environment in the salivary pellicles [11] [13] [14]. Recently, an SspB-derived analogous peptide, SspB (390-T400K-402), which has highaffinity binding to salivary gp340 peptide SRCRP2 [15], has been shown to competitively block S. mutans adhesion to experimental pellicles, thereby inhibiting biofilm formation [16].

Salivary gp340 has a high bacteria-binding capacity, and recognizes different bacterial receptors based on whether gp340 is in the fluid phase or is bound to the hydroxyapatite surface [17]. Absorption of this protein onto the surfaces of teeth promotes bacterial adherence, including that of S. mutans. Koba et al. [18] have demonstrated that SspB (A4K-A11K) has the highest binding activity to the salivary components and to SRCRP2 in comparison to several analogous SspB peptides. Therefore, we hypothesized that SspB (A4K-A11K) would be more effective to inhibit $S$. mutans biofilm formation without antimicrobial activity.

In the present study, to establish an assay that enables us to control cariogenic biofilms, we tested the inhibitory effects of SspB (A4K-A11K) on adherence and biofilm formation of S. mutans. The development of new antimicrobial compounds is essential for oral health research and for oral disease prevention strategies.

\section{Materials and Methods}

\subsection{Bacterial Culture}

Streptococcus mutans MT 8148 was maintained in brain heart infusion (BHI) broth or on Mitis-Salivarius (MS) agar plates (Formula/Liter: 15 g Enzymatic Digest of Casein, 5 g Enzymatic Digest of Animal Tissue, 50 g Sucrose, $1 \mathrm{~g}$ Dextrose, $4 \mathrm{~g}$ Dipotassium Phosphate, $0.075 \mathrm{~g}$ Trypan Blue, $0.0008 \mathrm{~g}$ Crystal Violet, $15 \mathrm{~g}$ Agar, Final pH: $7.0 \pm 0.2$ at $\left.25^{\circ} \mathrm{C}\right)$ under anaerobic conditions $\left(10 \% \mathrm{CO}_{2}, 10 \% \mathrm{H}_{2}\right.$ and $\left.80 \% \mathrm{~N}_{2}\right)$.

\subsection{Peptide Synthesis}

SspB (A4K-A11K) peptide, DYQKKLAAYQKEL, was constructed by substitution of K (lysine) for A (alanine) at position 4 and position 11 in the consensus sequence of Ssp peptides [18] (Table 1). Scavenger receptor cysteine-rich domain peptide 2, (SRCRP2), QGRVEVLYRGSWGTVC, on salivary gp340 [19] was used as a salivary component. Peptides were synthesized at $95 \%$ purity by Scrum, Inc. (Tokyo, Japan), and suspended in sterile distilled water (DW) at the desired concentration immediately before use.

\subsection{Human Saliva Collection}

As described previously [20], saliva samples were collected from volunteers in good oral health after stimulation by chewing paraffin gum. Volunteers had refrained from eating, drinking, and brushing for at least $2 \mathrm{~h}$ prior to collection. Saliva was placed in ice-chilled sterile bottles for $5 \mathrm{~min}$, followed by centrifugation at $10,000 \times g$ for $10 \mathrm{~min}$ at $4^{\circ} \mathrm{C}$ in order to remove cellular debris. Supernatants were filter sterilized through a $0.22-\mu \mathrm{m}$ Millex-GP

Table 1. Amino acid sequences of Ssp peptide substituted with lysine.

\begin{tabular}{cc}
\hline Peptide & Amino acid sequence \\
\hline Consensus sequence & ${ }^{1}$ D Y Q A K L A A Y Q A E L ${ }^{13 a}$ \\
SspB (A4K-A11K) & D Y Q K K K L A A Y Q K E L \\
\hline
\end{tabular}

${ }^{\mathrm{a}}$ Number indicated position in 13 mer amino acids residues. ${ }^{\mathrm{b}}$ The substituted amino acid with lysine was indicated in bold. 
filter (Merck Millipore, Bedford, MA, USA). After filtration, samples were pooled and stored at $-20^{\circ} \mathrm{C}$ until use.

\subsection{Detection of Saliva-Bound S. mutans}

To detect saliva-bacterium interactions, S. mutans was biotinylated [21] for enzyme-linked immunosorbent assay (ELISA). Cultures of $S$. mutans were washed with phosphate buffered saline (PBS). The bacterial cells were then biotinylated by incubation with NHS-LC-Biotin (Pierce) at $100 \mu \mathrm{g} / \mathrm{ml}$ for $1 \mathrm{~h}$ at room temperature. After washing with PBS, the bacterial concentration was adjusted to an optical density at $600 \mathrm{~nm}$ of 0.4 . Ninety-sixwell microtiter H-plates (Sumitomo Bakelite, Tokyo, Japan) were then coated with $100 \mu \mathrm{l}$ of sterile whole saliva or salivary agglutinin peptide SRCRP2 $(200 \mu \mathrm{g} / \mathrm{ml})$ for $1 \mathrm{~h}$ at $4{ }^{\circ} \mathrm{C}$. After two washes with PBS containing $0.1 \%$ Tween 20 (PBST), $100 \mu \mathrm{l}$ of biotinylated $S$. mutans cells were added and subsequently incubated for $1 \mathrm{~h}$ at $37^{\circ} \mathrm{C}$. The wells were then incubated for $1 \mathrm{~h}$ at $37^{\circ} \mathrm{C}$ with alkaline phosphatase-conjugated streptavidin (Invitrogen, Carlsbad, CA, USA) at a dilution of 1:1000. Subsequently, S. mutans adhered to saliva was detected by chromogenic development using para-nitrophenyl phosphate as the alkaline phosphatase substrate. After development, absorbance at $405 \mathrm{~nm}$ was measured and compared with control (non-treatment of saliva).

\subsection{Peptide Binding Assay}

Binding activity of SspB (A4K-A11K) peptide to saliva was detected by sandwich assay as described by Nakai et al. [22] with some modifications. We sandwiched whole saliva between biotinylated and non-biotinylated SspB (A4K-A11K) peptides. Briefly, 96-well microtiter H-plates were coated with SspB (A4K-A11K) $(650 \mu \mathrm{M})$ overnight at $4^{\circ} \mathrm{C}$. After $2 \mathrm{~h}$ blocking at $4^{\circ} \mathrm{C}$ with $1 \%$ bovine serum albumin (BSA) in PBS containing $1 \mathrm{mM}$ $\mathrm{CaCl}_{2}$ (Ca-PBS), human whole saliva was added $\left(100 \mu \mathrm{l}\right.$ per well) and incubated at $4^{\circ} \mathrm{C}$ for $1 \mathrm{~h}$. Biotinylated SspB (A4K-A11K) peptide $(650 \mu \mathrm{M})$ in $100 \mu \mathrm{l}$ of sterile DW was then applied to the wells; i.e., whole saliva was placed between SspB (A4K-A11K) and biotinylated SspB (A4K-A11K). Reactions were detected using the same ELISA protocol as mentioned above.

\subsection{Biofilm Formation Assay Using Hydroxyapatite Disks}

Biofilm formation assay using hydroxyapatite (HA) disks (10.0 mm diameter and $2.0 \mathrm{~mm}$ thickness; HOYA Technosurgical, Tokyo, Japan) as described by Ahn et al. [23] was performed with some modifications. Autoclaved HA disks were placed into 24-well microtiter plates and were coated with sterile whole saliva (s-HA) at $4^{\circ} \mathrm{C}$ overnight. After removing the saliva, $300 \mu \mathrm{l}$ of the SspB (A4K-A11K) peptide solution (650 $\mu \mathrm{M}$ in PBS) was added and incubated for $1 \mathrm{~h}$ at $37^{\circ} \mathrm{C}$. After two washes with sterile PBS, $50 \mu \mathrm{l}$ of $S$. mutans cell suspension $\left(6.3 \times 10^{6} \mathrm{CFU}\right)$ was added with $450 \mu \mathrm{l}$ of tryptic soy broth without dextrose supplemented with $0.25 \%$ sucrose (TSBS) and the culture was incubated anaerobically for 8,11 , or $14 \mathrm{~h}$ at $37^{\circ} \mathrm{C}$.

\subsection{Biofilm Evaluation}

The culture medium including planktonic cells and loosely bound cells was removed, and the disks were rinsed with sterile PBS. Each disk was transferred to a conical tube containing $3 \mathrm{ml}$ PBS. The adherent bacteria were detached by sonication using four 30-s pulses at $25 \mathrm{~W}$ with three 30-s intermittent cooling stages in an icechilled box. The cell suspensions were serially diluted and plated on MS agar, followed by a 2 day-incubation at $37^{\circ} \mathrm{C}$. The numbers of bacterial colonies were counted and expressed as colony forming units (CFUs). To provide further confirmation, we evaluated biofilms by measuring absorbance of safranin-stained biofilms on s-HA. After anaerobic incubation of $S$. mutans in TSBS $\left(8,11\right.$, and $14 \mathrm{~h}$ at $\left.37^{\circ} \mathrm{C}\right)$, formed biofilms on the disks were rinsed with sterile PBS and then air-dried. The disks were stained with safranin for $15 \mathrm{~min}$, followed by washing with DW to remove excess dye. The biofilm mass was quantified by measuring absorbance at $492 \mathrm{~nm}$.

\subsection{Statistical Analyses}

Data are expressed as means with standard deviation. IBM SPSS Statistics version 19 (IBM, Co., New York, CA) was used to assess significance. The statistical significance of differences between two groups was determined by unpaired $t$-tests. When the samples had unequal variances, unpaired $t$-tests with Welch's correction 
were used. For comparisons between multiple groups, one-way analysis of variance (ANOVA) and TukeyKramer tests were used. $P$-values less than 0.01 or 0.05 were considered to be statistically significant using two-tailed comparisons. All experiments were repeated and analyzed independently.

\section{Results}

\subsection{Adherence of S. mutans to Salivary Components}

To confirm the reproducibility of the $S$. mutans-saliva interaction, we performed ELISA where salivary components (whole saliva or salivary agglutinin peptide) were absorbed (Figure 1). When the wells were coated with the salivary gp340 peptide SRCRP2 $(200 \mu \mathrm{g} / \mathrm{ml})$, the highest adherence of $S$. mutans was observed of the tested conditions. Adherence of $S$. mutans to saliva-coated polystyrene plates was significantly higher than in DWcoated plates (control); however, it was lower than in the SRCRP2-coated condition. This suggests that salivary components, particularly gp340, promote adherence of $S$. mutans to polystyrene surfaces.

\subsection{Binding Abilities of SspB (A4K-A11K) to Whole Saliva}

Koba et al. [18] have demonstrated that SspB (A4K-A11K) peptide has the highest binding activity to salivary gp340 peptide SRCRP2 among several analogous SspB peptides. Hence, we hypothesized that SspB (A4KA11K) could inhibit $S$. mutans biofilms by competing for the same niche environment in the salivary pellicle. To assess this hypothesis, we examined the binding properties of the $\mathrm{SspB}$ peptide to saliva (Figure 2). First, a sandwich assay [22] with biotinylated and non-biotinylated SspB (A4K-A11K) peptide was performed to examine the interaction between the SspB peptide and salivary components (Figure 2). At peptide concentrations of $650 \mu \mathrm{M}$ (Figure 2(a)) and $1300 \mu \mathrm{M}$ (Figure 2(b)), SspB (A4K-A11K) that had bound to saliva exhibited a positive reaction in the sandwich assay. On the other hand, low reaction levels were observed with BSA, thus suggesting that SspB (A4K-A11K) peptide has saliva-binding ability. We found sufficient saliva-binding ability of SspB (A4K-A11K) at $650 \mu \mathrm{M}$ (Figure 2(a)); therefore, SspB at $650 \mu \mathrm{M}$ was used for further studies.

\subsection{Inhibitory Effects of SspB (A4K-A11K) on S. mutans Biofilm Formation on Saliva-Coated HA Disks}

We next examined whether SspB (A4K-A11K) is a potential inhibitor of $S$. mutans adherence to saliva and of its

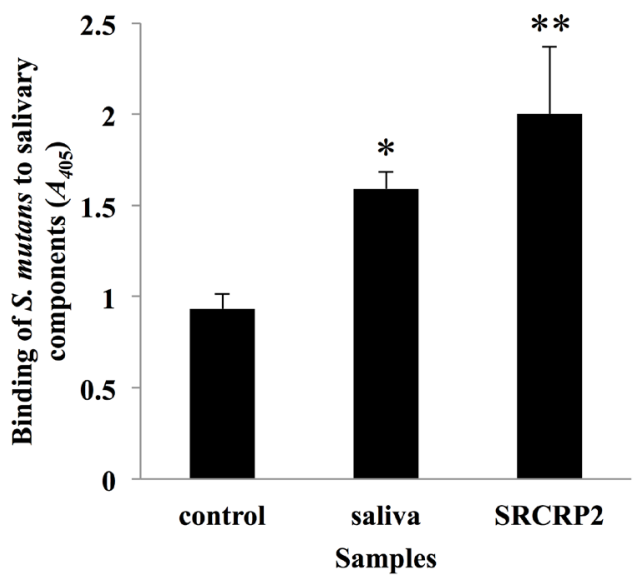

Figure 1. Adherence of $S$. mutans to saliva and to salivary agglutinin peptide SRCRP2. Binding response of biotinylated $S$. mutans to saliva and to salivary agglutinin peptide SRCRP2 $(200 \mu \mathrm{g} / \mathrm{ml})$. Binding is expressed as $A_{405}$ values obtained from three independent experiments. Values are expressed as means \pm standard deviation (SD) of triplicate assays. Asterisks denote significant differences (vs. control: DW; $\left.{ }^{*} P<0.05,{ }^{* *} P<0.01\right)$. 
biofilm formation; we therefore performed biofilm formation assays using saliva-coated HA disks (s-HA) (Figure 3). Biofilms were evaluated by counting CFUs on MS agar plates (Figure 3(a), Figure 3(b)). Pre-treatment with $650 \mu \mathrm{M}$ analogue peptide markedly reduced CFU counts compared to non-treatment at all culture times (Figure 3(a)). Decreased colony numbers on MS agar plates can be observed in photographs of SspB (A4K - A11K) pre-treatment conditions at all culture times (Figure 3(b)). To provide further confirmation, we evaluated biofilms by measuring the absorbance of safranin-stained biofilms on s-HA (Figure 3(c), Figure 3(d)). Pre-treatment with the SspB analogue peptide significantly diminished biofilm mass as compared with that of non-treatment groups at all culture times (Figure 3(c)). Inhibited biofilms on s-HA, stained in light color, can be observed for SspB (A4K-A11K) pre-treatment conditions at all culture times (Figure 3(d)). Furthermore, growth of $S$. mutans cultures in BHI was significantly inhibited with chlorhexidine $(0.04 \%)(P<0.01)$, whereas the peptide $(650 \mu \mathrm{M})$ did not affect bacterial growth (data not shown), suggesting that the SspB peptide has no bactericidal effect.

\section{Discussion}

Controlling dental plaque bacteria is important in the prevention and treatment of oral diseases. In the present study, we examined the inhibitory effects of SspB (A4K-A11K) on adherence and biofilm formation of S. mutans in order to establish an assay that enables us to control cariogenic biofilms.

We demonstrated that the streptococcal peptide analog SspB (A4K-A11K) derived from S. gordonii significantly inhibits cariogenic biofilm development formed by S. mutans (Figure 3). In addition, SspB (A4K-A11K) did not show bactericidal effects (data not shown) in our preliminary study, suggesting that the diminished biofilms are irrelevant to bactericidal activity. The use of this peptide enables us to control cariogenic biofilm formation without the risk of disruption of oral microbial communities.

SspB of S. gordonii and PAc of S. mutans interact with salivary components including lysozyme [24] [25], amylase [24], proline-rich proteins, and an agglutinin [26]. Pre-incubations of recombinant PAc (rPAc) with various concentrations of salivary agglutinin peptide SRCRP2 inhibit rPAc binding to salivary agglutinin in a dose-dependent manner, suggesting that the binding sites of PAc for SRCRP2 and agglutinin are identical or at least located in close proximity [19]. Furthermore, SspB (A4K-A11K) peptide has the highest response for binding to salivary components and to salivary gp340 peptide SRCRP2 when compared with other SspBs and streptococcal adhesin-derived peptides [15] [18]. These reports, together with our observations that SspB (A4KA11K) has binding activity with saliva (Figure 2), suggest that SspB (A4K-A11K) binds to salivary gp340. We believe that SspB (A4K-A11K) is markedly superior to other SspB-derived peptides with regard to sliva-binding

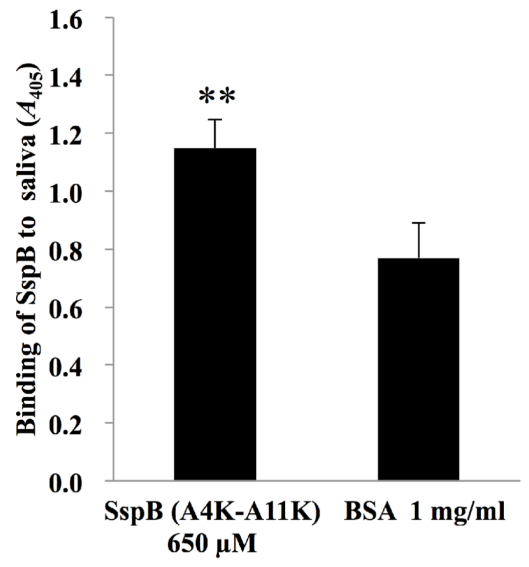

(a)

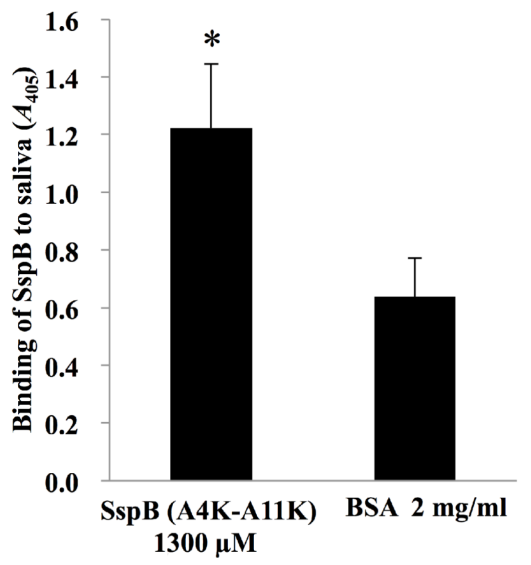

(b)

Figure 2. Sandwich assay with biotinylated and non-biotinylated SspB (A4K-A11K). (a) Microtiter plates were coated with non-biotinylated SspB (A4K-A11K) at $650 \mu \mathrm{M}$ and (b) at $1300 \mu \mathrm{M}$. Sterile saliva was added to the wells of coated plates, and then $650 \mu \mathrm{M}$ biotinylated SspB (A4K-A11K) was added. Data are expressed as $A_{405}$ values obtained from three independent experiments. Values are expressed as means $\pm \mathrm{SD}$ of triplicate assays (vs. control: BSA; ${ }^{*} P<0.05,{ }^{* *} P<0.01$ ). 


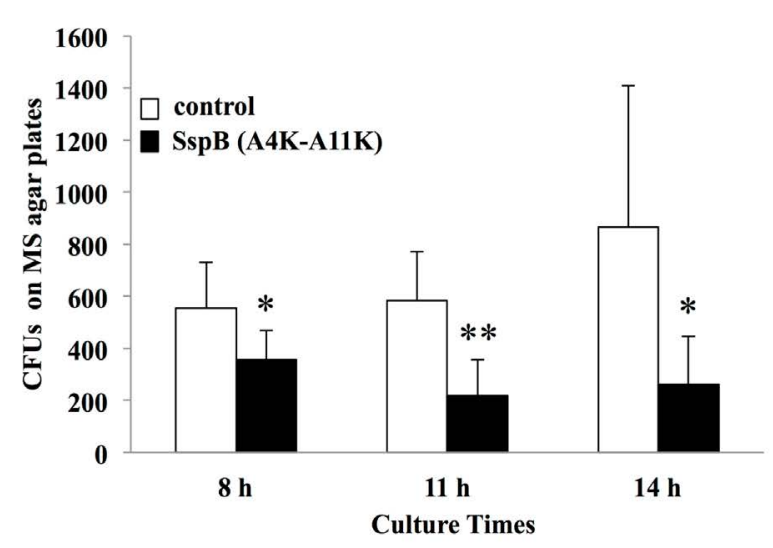

(a)

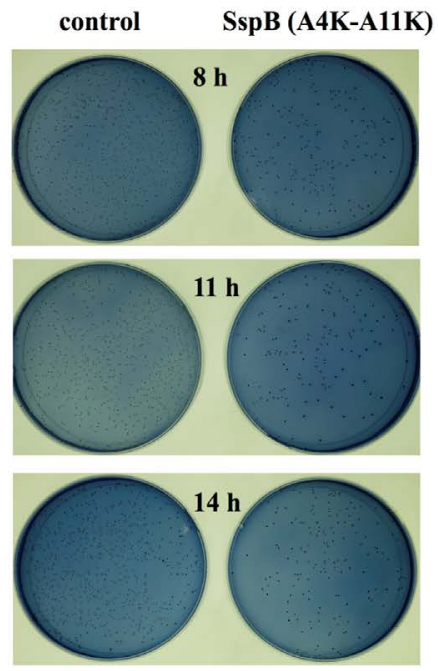

(b)
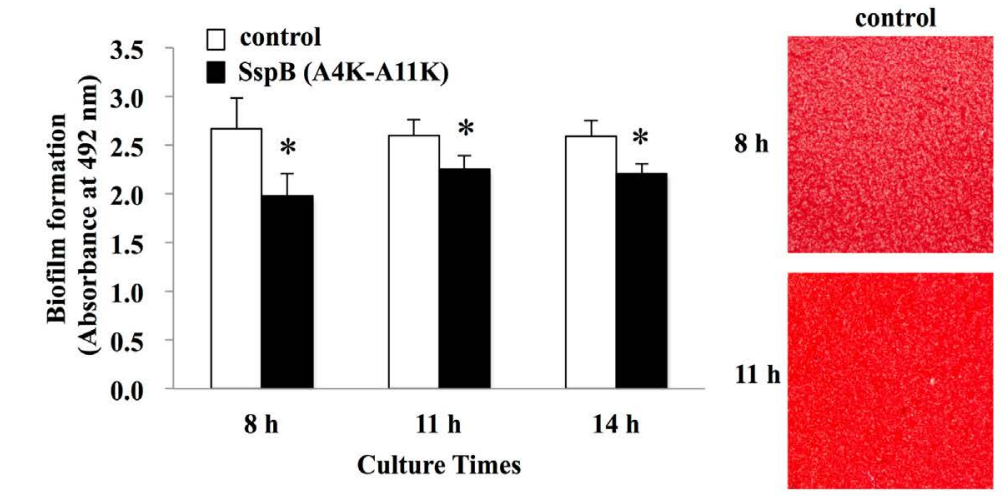

SspB (A4K-A11K)
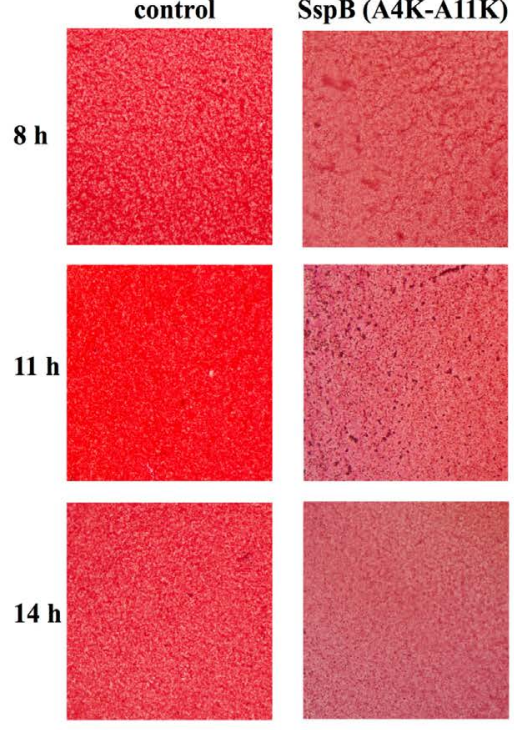

(c)

(d)

\begin{abstract}
Figure 3. Inhibition using SspB (A4K-A11K) of S. mutans biofilm formation on s-HA. (a) The amounts of biofilms were expressed as a colony forming unit (CFU). (b) Photographs of $S$. mutans colonies on MS agar plates at 8, 11, and $14 \mathrm{~h}$ culture $(40 \times)$. (c) Formed biofilms were stained with safranin and were measured the absorbance at $492 \mathrm{~nm}$. (d) Photographs of $S$. mutans biofilms on s-HA disks at 8,11 , and $14 \mathrm{~h}$ culture $(40 \times)$. Data are expressed as the means $\pm \mathrm{SD}$ of triplicate assays (vs. control: non-treated s-HA; ${ }^{*} P<0.05,{ }^{* *} P<0.01$ ).
\end{abstract}

characteristics.

Specific salivary proteins adsorbed onto enamel surfaces, e.g. acidic proline-rich proteins [4] and agglutinin [27], promote the adhesion of S. mutans by providing binding sites for bacterial adhesins. In addition, salivary sIgA, the predominant immunoglobulin found in all mucosal secretions, may promote colonization of certain strains of bacteria [28]. We previously demonstrated that salivary sIgA promotes the initial attachment of $S$. mutans on the mouse tooth surface [29]. In fact, saliva appears to have a significant impact on S. mutans adhesion to tooth surfaces. The increase in $S$. mutans binding to saliva-coated wells (Figure 1) suggests that the $S$. mutans-saliva interaction is reproduced in this assay. Moreover, the increase in the bacterial binding to SRCRP2coated wells (Figure 1 ) indicates that $S$. mutans interacts with salivary gp340. Indeed, rPAc has been demon- 
strated to bind to SRCRP2 [19]. These findings provide evidence that the S. mutans-saliva interaction observed in this study was not induced by salivary antibodies, but rather by salivary gp340. However, some limitations are worth noting. We did not confirm whether the saliva contains sIgA specific to $S$. mutans in the present study. This assay needs to be tested further by using sIgA purified from human saliva in order to compare the binding reactions with whole saliva and SRCRP2.

The Streptococcal peptide analog SspB (A4K-A11K) used in our study is constructed with lysine substitutions to express three positive charges, essential for binding to the negatively charged salivary components [16] and gp340 peptide SRCRP2 [18] on the peptide surface. We previously demonstrated that analogous SspB (390T400K-402) peptide can bind to the major periodontal pathogen Porphyromonas gingivalis by a substitution of lysine for threonine at position 400 of SspB (390-402), and consequently, the adhesion epitope of the peptide to $P$. gingivalis may be conferred by conformational changes [20]. We proposed a possible application of the analogous SspB (390-T400K-402) peptide to assess the relationships among SspB, P. gingivalis, and salivary gp340 as a unit [20]. Thus, further studies are still required to reveal the potential applications of SspB (A4K-A11K) to oral biology.

Okuda et al. have reported that SspB (390-T400K-402) inhibits adhesion of S. mutans to s-HA beads, while Streptococcus mitis, a major commensal microorganism of the oral cavity of healthy humans, was not affected [16]. This may be explained by the PAc-gp340 interaction being blocked by the SspB peptide. These findings, taking the above results (Figure 1 and Figure 2) together, suggest that SspB (A4K-A11K) may be a significant and specific inhibitor for the binding of $S$. mutans to s-HA by blocking the PAc-gp340 interaction. Provided that the SspB peptide is introduced to the oral cavity, $S$. mutans may be excluded followed by immediate recolonization of $S$. mitis on the tooth surface to keep a healthy oral flora, excluding the cariogenic bacteria.

Overall, these results suggest that the inhibitory effects on S. mutans biofilms by using SspB (A4K-A11K) presented herein are due to competitive inhibition of adherence of the bacteria to salivary gp340. Therefore, the SspB (A4K-A11K) peptide binding assay developed here will provide important insights into the development and employment of anti-adherence peptides in future therapies that enable us to control cariogenic biofilms.

\section{Conclusion}

Analogous SspB (A4K-A11K) peptide inhibits biofilm formation of S. mutans on saliva-coated hydroxyapatite disks. This is attributed to competitive inhibition of $S$. mutans adhesion to saliva. This study will contribute to the progress of therapy for oral infections.

\section{Acknowledgements}

We thank Hidenobu Senpuku (National Institute of Infectious Diseases, Tokyo, Japan) for his helpful discussions and advice. We also thank all volunteers for their cooperation in this study. This work was supported by a Grant-in-Aid for Young Scientists (B) 15K20610 from the Ministry of Education, Culture, Sports, Science and Technology of Japan.

\section{References}

[1] Hamada, S. and Slade, H.D. (1980) Biology, Immunology, and Cariogenicity of Streptococcus mutans. Microbiological Reviews, 44, 331-384.

[2] Loesche, W.J. (1986) Role of Streptococcus mutans in Human Dental Decay. Microbiological Reviews, 50, $353-380$.

[3] Liljemark, W.F. and Bloomquist, C. (1996) Human Oral Microbial Ecology and Dental Caries and Periodontal Diseases. Critical Reviews in Oral Biology \& Medicine, 7, 180-198.

[4] Gibbons, R.J. (1989) Bacterial Adhesion to Oral Tissues: A Model for Infectious Diseases. Journal of Dental Research, 68, 750-760. http://dx.doi.org/10.1177/00220345890680050101

[5] Bikker, F.J., Ligtenberg, A.J., Nazmi, K., Veerman, E.C., van’t Hof, W., Bolscher, J.G., Poustka, A., Nieuw, Amerongen, A.V. and Mollenhauer, J. (2002) Identification of the Bacteria-Binding Peptide Domain on Salivary Agglutinin (gp-340/DMBT1), a Member of the Scavenger Receptor Cysteine-Rich Superfamily. Journal of Biological Chemistry, 277, 32109-32115. http://dx.doi.org/10.1074/jbc.M203788200

[6] Okahashi, N., Sasakawa, C., Yoshikawa, M., Hamada, S. and Koga, T. (1989) Cloning of a Surface Protein Antigen Gene from Serotype c Streptococcus mutans. Molecular Microbiology, 3, 221-228.

http://dx.doi.org/10.1111/j.1365-2958.1989.tb00215.x 
[7] Russell, M.W., Bergmeier, L.A., Zanders, E.D. and Lehner, T. (1980) Protein Antigens of Streptococcus mutans: Purification and Properties of a Double Antigen and Its Protease-Resistant Component. Infection and Immunity, 28, 486493.

[8] Russell, R.R. (1979) Wall-Associated Protein Antigens of Streptococcus mutans. Journal of General Microbiology, 114, 109-115. http://dx.doi.org/10.1099/00221287-114-1-109

[9] Forester, H., Hunter, N. and Knox, K.W. (1983) Characteristicsof a High Molecular Weight Extracellular Protein of Streptococcus mutans. Journal of General Microbiology, 129, 2779-2788.

[10] Demuth, D.R., Lammey, M.S., Huck, M., Lally, E.T. and Malamud, D. (1990) Comparison of Streptococcus mutans and Streptococcus sanguis Receptors for Human Salivary Agglutinin. Microbial Pathogenesis, 9, 199-211. http://dx.doi.org/10.1016/0882-4010(90)90022-I

[11] Nobbs, A.H., Zhang, Y., Khammanivong, A. and Herzberg, C. (2007) Streptococcus gordonii Hsa Environmentally Constrains Competitive Binding by Streptococcus sanguinis to Saliva-Coated Hydroxyapatite. Journal of Bacteriology, 189, 3106-3114. http://dx.doi.org/10.1128/JB.01535-06

[12] Demuth, D.R., Duan, Y., Brooks, W., Holmes, A.R., McNab, R. and Jenkinson, H.F. (1996) Tandem Genes Encode Cell-Surface Polypeptides SspA and SspB Which Mediate Adhesion of the Oral Bacterium Streptococcus gordonii to Human and Bacterial Receptors. Molecular Microbiology, 20, 403-413. http://dx.doi.org/10.1111/j.1365-2958.1996.tb02627.x

[13] Appelbaum, B., Golub, E., Holt, S.C. and Rosan, B. (1979) In Vitro Studies of Dental Plaque Formation: Adsorption of Oral Streptococci to Hydroxyaptite. Infection and Immunity, 25, 717-728.

[14] Liljemark, W.F. and Schauer, S.V. (1977) Competitive Binding among Oral Strptococci to Hydroxyapatite. Journal of Dental Research, 56, 157-165.http://dx.doi.org/10.1177/00220345770560021001

[15] Hamada, T., Kawashima, M., Watanabe, H., Tagami, J. and Senpuku, H. (2004) Molecular Interactions of Surface Protein Peptides of Streptococcus gordonii with Human Salivary Components. Infection and Immunity, 72, 4819-4826. http://dx.doi.org/10.1128/IAI.72.8.4819-4826.2004

[16] Okuda, K., Hanada, N., Usui, Y., Takeuchi, H., Koba, H., Nakao, R., Watanabe, H. and Senpuku, H. (2010) Inhibition of Streptococcus mutans Adherence and Biofilm Formation Using Analogues of the SspB Peptide. Archives of Oral Biology, 55, 754-62. http://dx.doi.org/10.1016/j.archoralbio.2010.06.014

[17] Loimaranta, V., Jakubovics, N.S., Hytonen, J., Finne, J., Jenkinson, H.F. and Stromberg, N. (2005) Fluid- or SurfacePhase Human Salivary Scavenger Protein gp340 Exposes Different Bacterial Recognition Properties. Infection and Immunity, 73, 2245-2252. http://dx.doi.org/10.1128/IAI.73.4.2245-2252.2005

[18] Koba, H., Okuda, K., Watanabe, H., Tagami, J. and Senpuku, H. (2009) Role of Lysine in Interaction between Surface Protein Peptides of Streptococcus gordonii and Agglutinin Peptide. Oral Microbiology and Immunology, 24, 162-169. http://dx.doi.org/10.1111/j.1399-302X.2008.00490.x

[19] Oho, T., Bikker, F.J., Nieuw, Amerongen, A.V. and Groenink, J. (2004) A Peptide Domain of Bovine Milk Lactoferrin Inhibits the Interaction between Streptococcal Surface Protein Antigen and a Salivary Agglutinin Peptide Domain. Infection and Immunity, 72, 6181-6184. http://dx.doi.org/10.1128/IAI.72.10.6181-6184.2004

[20] Ito, T., Senpuku, H., Ichinosawa, T., Ito-Ikematsu, N., Kimura, N. and Shimizu, T. (2015) SspB Peptide Assay Reveals Saliva-Mediated Porphyromonas gingivalis Attachment. Open Journal of Stomatology, 5, 259-267. http://dx.doi.org/10.4236/ojst.2015.511032

[21] Ruhl, S., Cisae, J.O. and Sandberg, A.L. (2000) Identification of Polymorphonuclear Leukocyte and HL-60 Cell Receptors for Adhesins of Streptococcus gordonii and Actinomyces naeslundii. Infection and Immunity, 68, 6346-6354. http://dx.doi.org/10.1128/IAI.68.11.6346-6354.2000

[22] Nakai, M., Okahashi, N., Ohta, H. and Koga, T. (1993) Saliva-Binding Region of Streptococcus mutans Surface Protein Antigen. Infection and Immunity, 61, 4344-4349.

[23] Ahn, S.G., Cho, E.J., Oh, S.S. and Lim, B.S. (2012) The Effects of Orthodontic Bonding Steps on Biofilm Formation of Streptococcus mutans in the Presence of Saliva. Acta Odontologica Scandinavica, 70, 504-510. http://dx.doi.org/10.3109/00016357.2011.640277

[24] Russell, M.W. and Mansson-Rahemtulla, B. (1989) Interaction between Surface Protein Antigens of Streptococcus mutans and Human Salivary Components. Oral Microbiology and Immunology, 4, 106-111. http://dx.doi.org/10.1111/j.1399-302X.1989.tb00107.x

[25] Senpuku, H., Kato, H., Todoroki, M., Hanada, N. and Nishizawa, T. (1996) Interaction of lysozyme with a Surface Protein Antigen of Streptococcus mutans. FEMS Microbiology Letters, 139, 195-201. http://dx.doi.org/10.1111/j.1574-6968.1996.tb08202.x

[26] Demuth, D.R., Golub, E.E. and Malamud, D. (1990) Streptococcal-Host Interactions. Structural and Functional Analysis of a Streptococcus sanguis Receptor for a Human Salivary Glycoprotein. The Journal of Biological Chemistry, 265, 
7120-7126.

[27] Brady, L.J., Piacentini, D.A., Crowley, P.J., Oyston, P.C. and Bleiweis, A.S. (1992) Differentiation of Salivary Agglutinin-Mediated Adherence and Aggregation of Mutans Streptococci by Use of Monoclonal Antibodies against the Major Surface Adhesin P1. Infection and Immunity, 60, 1008-1017.

[28] Lamont, R.J., Demuth, D.R., Davis, C.A., Malamud, D. and Rosan, B. (1991) Salivary-Agglutinin-Mediated Adherence of Streptococcus mutans to Early Plaque Bacteria. Infection and Immunity, 59, 3446-3450.

[29] Ito, T., Maeda, T. and Senpuku, H. (2012) Roles of Salivary Components in Streptococcus mutans Colonization in a New Animal Model Using NOD/SCID.e2f1 ${ }^{-/-}$Mice. PLoS ONE, 7, e32063. http://dx.doi.org/10.1371/journal.pone.0032063 